Cheshire, formed by public subscription in memory of the late T. A. Coward, sometime lecturer in the University of Manchester and author of "The Birds of Cheshire", "The Fauna of Cheshire", etc. The deeds were handed over to the Society for the Promotion of Nature Reserves. The Earl of Stamford, chairman of the memorial committee, said 1,570 people from all parts of the world had subscribed $£ 925$ to save this well-known haunt of fauna and flora, and also a second memorial sanctuary at Marbury Mere, and subscriptions coming from so far apart as Canada and Hong-Kong showed the wide appreciation of Mr. Coward's work. The sanctuaries were chosen not only for their own particular appropriateness and value for study, but also because Coward himself studied in them so often. One part of the sanctuary will be permanently closed as a true Nature sanctuary for wild life, but a public right of way will exist at another part where visitors can see down the sanetuary and hear the bird songs. A bronze memorial plaque on a glacial boulder brought from the Bollin Valley is inscribed: "In Memory of Thomas Alfred Coward, M.Sc.,-18671933 - Cotterill Clough and Marbury Reed Bed were purchased by public subscription to remain for ever undisturbed Nature reserves as a memorial to his great services to natural science". Already studies have been made in the sanctuary by the Manchester branch of the British Empire Naturalists' Association and the Altrincham Natural History Society. The opening ceremony in the Clough was attended by delegates from natural history, scientific, ramblers, and other bodies chiefly from the north of England.

\section{Recent Archæological Discoveries in Crete}

OPPORTUNITY for further study of the archæological material found in a cave at Arkalokhori in Crete (see Nature, July 6, p. 15) has led to some modification of opinion as to its character, though not as to its importance. Sir Arthur Evans, in a communication to The Times of July 29, states that as a result of comparative study of the hieroglyphic inscription in three vertical lines on the votive bronze double axe, he has arrived at the conclusion that it does not, as at first supposed, represent an exotic script. He finds that while one or two new forms appear, nearly all the signs have close parallels in the Cretan series, while two recur in the same collocation on a faceted hieroglyphic eylinder in his possession. $\mathrm{He}$ is, therefore, of the opinion that the language is identical, though the new inscription, from its associations with material belonging to Late Middle Minoan, must be regarded as late in its class, dating from about 1600 B.c. From one of the lairs of a badger, from which animal the locality takes its name, a fairly complete series of potsherds, covering most of the Minoan periods, was recovered. Sir Arthur, passing on in the same communication to recent work at Knossos, chronicles an exploration of Minoan deposits, in which the most remarkable discovery was a small limestone head. This was of a markedly dolichocephalic early Egyptian type, though associated with relies of the closing Middle
Minoan age. Mosaics of Hadrianic age from a villa recently found in the vineyard of the Villa Ariadne, in which the heads of Dionysiac figures in medallions are the recurring subject, have been pronounced to excel any Roman specimens of the kind yet found in Greece.

\section{Origins of Man in America}

SEARCH for evidence bearing on the problem of early man in America, which has been carried on in New Mexico during the past five years by Mr. Edgar B. Howard under the auspices of the Academy of Natural Sciences and the University Museum, Philadelphia, is now to be extended farther afield. When it was announced a few years ago that the stone implements of a type hitherto unknown in America, but now known as 'Folsom points', had been discovered near Folsom, New Mexico, by Prof. E. B. Renaud, of the University of Denver, a new orientation was given to the study of American archæology, more especially in the attitude towards alleged associations of artefacts with the bones of extinct or presumedly early fauna. An antiquity for man in America greater than that generally admitted seemed a possibility. Mr. Howard's ex. plorations in New Mexico, of which an account is to appear in the Museum Journal (Philadelphia), and especially his discoveries in a cave west of Carlsbad and in old lake beds near Clovis, New Mexico, at a depth of eight feet, of artefacts and traces of camp fires in association with the remains of extinct fauna-camels, wild horse, elephants-indicate that Folsom man had penetrated to the south-west in Pleistocene times, when the Wisconsin ice-sheet was waning, a period of climatic change tentatively fixed at 10,000 years ago. No contemporary human remains have been found. Mr. Howard is of the opinion that further evidence must be sought in Asia, and is now on his way, with the assistance of the Philadelphia Academy of Natural Sciences, to Russia, where he proposes to study the archæology of Siberia and hopes to enlist the co-operation of the Soviet authorities in further exploration. In the meantime, Dr. F. de Laguna, also on behalf of the Philadelphia Academy of Natural Sciences, has resumed her researches in Alaska-on this occasion in the Yukon Valley and with the object of tracking Folsom man on his way to the south-west.

\section{Marriage Hygiene}

A NEW quarterly journal, Marriage Hygiene, with a strong editorial board consisting, for the time being, of a number of prominent Indian medical men, has recently appeared from the Times of India Press, Bombay. Its objects are to secure for the science of conjugal hygiene a proper place in preventive medicine, to publish contributions which are believed to be necessary for scientific, sane sex teaching, and to bind its readers together into a brotherhood of clean thinkers and bold fighters against prejudice and taboos; and it is intended, by additions to the editorial board, that the journal should become an international one. The first number consists of 